\title{
FDI, income inequality and poverty: a time series analysis of Portugal, 1973-2016
}

\author{
Aurora A. C. Teixeira ${ }^{1,2,3}$ (D) \& Ana Sofia Loureiro ${ }^{1}$ \\ Received: 30 August 2017 / Accepted: 17 December 2018 / Published online: 15 January 2019 \\ \# ISEG - Instituto Superior de Economia e Gestão 2019
}

\begin{abstract}
Using time series data for Portugal between 1973 and 2016, this paper examines to what extent, inward FDI contributes to income inequality and poverty in the long-run. It was found that increased flows of inward FDI are associated with a less unequal income distribution and lower poverty rates. The results further suggest that, in the Portuguese case there is mutual causality between inward FDI and poverty in the long run, i.e., FDI significantly reduces poverty, and lower levels of poverty lead to higher inward FDI flows. In the case of inequality, the evidence shows that FDI does not contribute to higher (or lower) income inequality. Instead, more unequal income distributions significantly and negatively impact on inward FDI in the long run. Finally, human capital emerged as a key determinant to mitigate income inequality and circumvent poverty, contributing, indirectly, to fostering additional FDI inflows. Such results call for integrated public policy interventions that emphasize social and institutional dimensions.
\end{abstract}

Keywords FDI $\cdot$ Inequality $\cdot$ Poverty $\cdot$ Portugal $\cdot$ Johansen cointegration $\cdot$ Granger (non-) causality

JEL classifications $\mathrm{D} 63 \cdot \mathrm{I} 32 \cdot \mathrm{F} 30 \cdot \mathrm{O} 52 \cdot \mathrm{C} 32$

* Aurora A. C. Teixeira

ateixeira@fep.up.pt

Ana Sofia Loureiro

anasofialoureiro91@gmail.com

1 CEF.UP, Faculdade de Economia do Porto, Universidade do Porto, Rua Dr Roberto Frias, 4200-464 Porto, Portugal

2 INESC TEC, Porto, Portugal

3 OBEGEF, Porto, Portugal 